\title{
HSP90B1 wt Allele
}

National Cancer Institute

\section{Source}

National Cancer Institute. HSP9OB1 wt Allele. NCI Thesaurus. Code C117269.

Human HSP90B1 wild-type allele is located within 12q24.2-q24.3 and is approximately 24 $\mathrm{kb}$ in length. This allele, which encodes endoplasmin protein, is involved in ATP-hydrolysis dependent post-translational protein processing. 